EISSN: 2706-7955 ISSN: 2077-4605

DOI: 10.36632/mejar/2021.10.3.66

Journal homepage: www.curresweb.com

Pages: 1014-1025

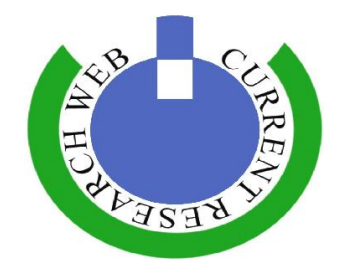

\title{
Effect of Coating and Wrapping on Postharvest Quality of Manfalouty Pomegranate Fruits under Cold Storage
}

\author{
Masoud A.A.B., Fatma Alzhraa M. Hamdy, Mohamed. M. EL-Akkad, Rashad A. \\ Ibrahim and Eman A.A. Abou-Zaid
}

Department of Pomology, Faculty of Agriculture, Assiut University, Egypt

\author{
Received: 15 August $2021 \quad$ Accepted: 14 Sept. $2021 \quad$ Published: 30 Sept. 2021
}

\begin{abstract}
The study was performed to evaluate the influence of coating and wrapping treatments used singly or in combination on improving postharvest quality of Manfalouty pomegranate cultivar during 2019 and 2020 seasons. Fruits were coated with any of turmeric oil or ginger oil at $10 \%$ and wrapped with waxed paper then stored under cold conditions at $\left(7^{\circ} \mathrm{C}\right)$ with R.H $85-90 \%$ and analyzed at 2-week intervals to study the changes in physical and chemical quality of fruits. The obtained results revealed that by prolong storage period all the studied fruit properties (fruit weight loss $\%$, fruit decay $\%$, total soluble solids $\%$ and reducing sugar $\%$ ) were increased significantly. However, total acidity $\%$ was decreased. All tested treatments had a significant effect on reducing changes in the above mentioned quality parameters but the coating with essential oils, when combined with waxed paper surpassed other treatments in controlling weight and decay. Also, the highest content of total acidity and the lowest percentage of total soluble solids and reducing sugar were recorded in fruits treated with essential oils when combined with waxed paper. Therefore, it could be recommended to use turmeric and ginger essential oils coating in combination with the waxed paper wrapping for improving quality and prolong the storage life of pomegranate fruits. Moreover, the previous treatments can provide a safe and healthy product as they are an alternative to harmful chemical applications
\end{abstract}

Keywords: Manfalouty pomegranate, turmeric oil, ginger oil, waxed paper, Cold storage

\section{Introduction}

Pomegranate is considered as one of the most important crops due to the expansion of its cultivation in many tropical and subtropical countries of the world such as Egypt, Tunisia, Morocco, Pakistan, Iran, Afghanistan, India, Spain, Turkey and USA. This due to that pomegranate trees have high resistance in dry climate and they can grow under different climatic conditions (Holland et al., 2009).

There are many cultivars of pomegranate. In Egypt, the most popular cultivars of pomegranate are Manfalouty, El-Araby, Wonderfull, El-Hijazi, Wardy and Nab ElGamal. Manfalouty considered the most important and luxurious cultivar which grown widely in Upper Egypt, particularly Assiut governorate.

Pomegranate is non-climacteric fruit, however it exposed to qualitative and quantitative loss that due to postharvest handling processes (Kader et al., 1984). Therefore, recently, interest has increased in research on postharvest storage of pomegranate fruits and finding some physical applications to preserve fruits quality for the longest storage period including modified atmosphere packaging, fruit wrapping with different materials and edible coating (Hayat et al., 2005, D'Aquino et al., 2010 and Shaarawi \& Nagy, 2017).

Herbal coating such as Turmeric, ginger, Lemongrass, Neem, Ocimum and cinnamon etc; are used as alternative method to chemical coating for preserving fruit quality because of their film shaping and antibacterial properties and their high antioxidants, vitamins and minerals content. Turmeric and ginger are one of the plants of the Zingiberaceae family. The essential oils extracted from these plants Corresponding Author: Masoud A.A.B., Department of Pomology, Faculty of Agriculture, Assiut University, Egypt 
used as edible coatings because of its antibacterial and antioxidant properties (Tripathi, 2008 and Jemilakshm et al., 2020).

Wrapping of fresh fruits and vegetables is one of the most applications that have an important role in prolong fruits storage period by reducing the physiological disorders after harvest (Kader \& Arpaia, 2002), through controlling the respiration rate and metabolism of the wrapped product, modifying the atmosphere around the product by changing the ratios of oxygen and carbon dioxide (Yamashita et al., 2002).

Therefore, the aim of this investigation was to study the effect of some postharvest treatments including coating with ginger oil, turmeric oil, and wrapping fruits with waxed paper on the quality and storability of Manfalouty pomegranate cultivar under cold storage.

\section{Materials and Methods}

This study was conducted on Manfalouty Pomegranate fruits which were harvested from experimental orchard of Pomology Department, Faculty of Agriculture, Assiut University during two successive seasons of 2019 and 2020. Fruits were carefully collected in the appropriate stage of maturity. They were healthy and free from diseases, insects, defects and mechanical damage. Fruits were collected manually and placed in the shade in the orchard for 24 hours to exclude any damaged and infected fruits, in the second day about 306 non-defective fruits transported to the laboratory of pomology department Science. The fruits were cleaned, weighted and washed by tap water and then left in air to dry. Fruits were divided into six equal groups for six different treatments as follows:

- Control group (untreated fruits)

- Coating fruits with turmeric oil $10 \%$

- Coating fruits with ginger oil $10 \%$

- Wrapping fruits with waxed paper

- Coating fruits with turmeric oil $10 \%+$ Wrapping fruits with waxed paper

- Coating fruits with ginger oil $10 \%+$ Wrapping fruits with waxed paper

Each treatment was consisted of three replicates. Fruits were stored in a refrigerator at $\left(7{ }^{\circ} \mathrm{C}\right)$ with R.H 85-90\%. Five fruits per replication from each treatment (total fifteen fruits from each treatment) were selected for decay percentage determination and weight loss percentage. Fruits were exposed to quality evaluation every two weeks. The fruits quality was evaluated by studying the changes in some physical and chemical characteristics.

\subsection{Measurements}

\section{Physical characteristic}

\section{Percentage of Fruit Weight loss}

The physiological loss in weight of fruits was scored by using an electronic balance. Pomegranate fruits were weighted at the beginning of the storage period (initial weight). Initial weight was compared with the weight at the specified time of sampling. Weight loss was expressed as percentage using the following equation:

$$
\text { Fruit weight loss } \%=\frac{\text { Initial weight }(\mathrm{g})-\text { Weight at the time of sampling }(\mathrm{g})}{\text { Initial weight }(\mathrm{g})} \times 100
$$

\section{Percentage of Fruit Decay}

Fruits appearing any visible decay were counted and calculated according to the following equation as percentage:

$$
\text { Fruit decay } \%=\frac{\text { Total number of decayed fruits }}{\text { Total number of initial stored fruits }} \times 100
$$




\subsection{Chemical Characteristics}

\section{Total Soluble Solids percentage (TSS \%)}

Total soluble solids in extracted juice from arils were measured by a hand refractometer according to Chen \& Mellenthin (1981).

\section{Total Acidity percentage (TA \%) :}

Total Acidity (TA) was determined by titrating $10 \mathrm{ml}$ of diluted juice against $0.1 \mathrm{~N} \mathrm{NaOH}$ solution and phenolphthalein as indicator. TA was calculated as grams of citric acid (CA) per $100 \mathrm{ml}$ of juice of arils and TA \% was calculated by the following equation according to AOAC (2005):

$$
\text { Total Acidity } \%=\frac{\mathrm{ML}(\mathrm{s}) \mathrm{NaOH} \times \text { standard solution of } \mathrm{NaOH}(\mathrm{N}) \times 64}{1000 \times \text { The volume of used juice }} \times 100
$$

* Standard solution of $\mathrm{NaOH}(\mathrm{N})=0.1 \mathrm{~N}$

*64 = the equivalent weight of citric acid

$*$ The volume of used juice $=10 \mathrm{ml}$

\section{Reducing sugars percentage:}

Reducing sugars percentage in the juice was measured according to Lane and Eynon procedure according to AOAC (1985).

\subsection{Statistical analysis}

The experiment includes two factors arranged in a split-plot design with three replicates. Periods of storage assigned in main plot and studied treatments were considered as the sup-plot. The obtained data were statistically analyzed according to Snedecor \& Cochran (1990) by using Statistix 8.1 software Analytical Software (2005) using L.S.D test at $5 \%$ of probability to evaluate the significant difference among various treatment means.

\section{Results}

\subsection{Effect of some essential oils and waxed paper wrapping on physical characteristics Percentage of fruit weight loss}

The results in Table 1 showed that weight loss percentage was increased by extending the storage duration. Also, all tested treatments significantly decreased the fruit weight loss percentage compared with untreated fruits. Data related to treatments averages showed that turmeric oil and ginger oil in combination with waxed paper gave the best results, which scored the lowest fruit weight loss values $(15.22 \% \& 15.29 \%)$ and $(16.75 \% \& 17.03 \%)$ during both studied seasons, respectively compare to control (untreated fruits) which scored the highest weight loss values $(22.59 \% \& 21.65 \%)$ during 2019 and 2020 seasons, respectively.

The interaction between storage treatments and storage periods had significant effect, it was noticed that all treatments had the lowest percentage of fruits weight loss at the end of storage period compared to control. On the other hand, the minimum values of weight loss percentage $(28.96 \%$ \& $28.89 \%)$ and $(29.07 \%$ \& $29.30 \%)$ were obtained from treated fruits with turmeric oil plus waxed paper and ginger oil plus waxed paper during both tested seasons, respectively compared to the maximum percentages ( $35.74 \%$ \& $33.70 \%$ ) were due to control in 2019 and 2020 seasons, respectively.

\section{Percentage of fruit decay}

According to data in Table 2, it was clear that the decay percentage of fruits was increased with the prolonging of the storage period; however, there was no decay till $10^{\text {th }}$ week. It was clear that all treatments significantly reduced the undesirable fruit percentage compared with untreated fruits however, comparison of treatments means cleared that there was no significant difference between ginger oil treatment and control in both studied seasons. 
Table 1: Effect of coating with some essential oils and wrapping with waxed paper on weight loss \% of "Manfalouty" pomegranate fruits under cold storage during 2019 and 2020 seasons.

\begin{tabular}{|c|c|c|c|c|c|c|c|c|c|c|c|c|}
\hline \multirow[b]{2}{*}{ Treatment } & \multicolumn{12}{|c|}{ Weeks of cold storage in Season 2019} \\
\hline & $\mathbf{0}$ & 2 & 4 & 6 & 8 & 10 & 12 & 14 & 16 & 18 & 20 & Mean \\
\hline Control & 0.00 & 8.50 & 13.49 & 19.48 & 23.01 & 25.16 & 27.60 & 30.07 & 31.82 & 33.58 & 35.74 & 22.59 \\
\hline Turmeric oil & 0.00 & 6.29 & 10.30 & 14.84 & 18.28 & 21.80 & 24.32 & 26.09 & 28.20 & 29.49 & 30.51 & 19.10 \\
\hline Ginger oil & 0.00 & 7.47 & 11.70 & 14.95 & 21.49 & 23.62 & 27.26 & 29.71 & 30.58 & 32.95 & 34.26 & 21.27 \\
\hline Waxed Paper & 0.00 & 7.57 & 12.44 & 16.40 & 18.82 & 22.51 & 25.30 & 27.34 & 29.18 & 31.36 & 33.06 & 20.36 \\
\hline $\begin{array}{l}\text { Turmeric oil + waxed } \\
\text { paper }\end{array}$ & 0.00 & 4.26 & 7.74 & 9.35 & 12.39 & 15.23 & 17.80 & 20.91 & 24.41 & 26.33 & 28.96 & 15.22 \\
\hline Ginger oil + waxed paper & 0.00 & 3.56 & 7.85 & 9.68 & 12.32 & 14.92 & 18.31 & 21.85 & 24.48 & 26.32 & 28.89 & 15.29 \\
\hline Mean & 0.00 & 6.28 & 10.59 & 14.12 & 17.72 & 20.54 & 23.43 & 26.00 & 28.11 & 30.01 & 31.90 & 18.97 \\
\hline \multirow{3}{*}{ LSD \% } & Period & & 0.39 & & & & & & & & & \\
\hline & Treatn & & 0.30 & & & & & & & & & \\
\hline & Period & eatment & 0.99 & & & & & & & & & \\
\hline & \multicolumn{12}{|c|}{ Weeks of cold storage in Season 2020} \\
\hline $\begin{array}{l}\text { Period } \\
\text { Treatment }\end{array}$ & $\mathbf{0}$ & 2 & 4 & 6 & 8 & 10 & 12 & 14 & 16 & 18 & 20 & Mean \\
\hline Control & 0.00 & 7.41 & 13.57 & 18.57 & 21.21 & 24.74 & 26.71 & 28.67 & 30.64 & 32.89 & 33.70 & 21.65 \\
\hline Turmeric oil & 0.00 & 5.83 & 11.22 & 16.34 & 19.21 & 22.36 & 24.21 & 26.27 & 29.38 & 30.89 & 32.59 & 19.85 \\
\hline Ginger oil & 0.00 & 6.44 & 12.14 & 17.79 & 20.19 & 23.55 & 25.73 & 27.46 & 29.87 & 31.44 & 32.59 & 20.65 \\
\hline Waxed Paper & 0.00 & 6.31 & 12.22 & 17.47 & 20.44 & 23.62 & 25.13 & 27.31 & 29.65 & 31.55 & 32.67 & 20.58 \\
\hline $\begin{array}{l}\text { Turmeric oil + waxed } \\
\text { paper }\end{array}$ & 0.00 & 3.49 & 7.23 & 12.18 & 15.38 & 18.57 & 21.42 & 23.51 & 25.89 & 27.47 & 29.07 & 16.75 \\
\hline Ginger oil + waxed paper & 0.00 & 4.29 & 7.54 & 12.31 & 16.53 & 18.67 & 21.88 & 23.09 & 25.92 & 27.83 & 29.30 & 17.03 \\
\hline Mean & 0.00 & 5.63 & 10.65 & 15.78 & 18.83 & 21.92 & 24.18 & 26.05 & 28.56 & 30.34 & 31.65 & 19.42 \\
\hline \multirow{3}{*}{ LSD \% } & Period & & 0.19 & & & & & & & & & \\
\hline & \multicolumn{2}{|c|}{ Treatment } & 0.11 & & & & & & & & & \\
\hline & \multicolumn{2}{|c|}{ Period ${ }^{*}$ Treatment } & 0.38 & & & & & & & & & \\
\hline
\end{tabular}


Table 2: Effect of coating with some essential oils and wrapping with waxed paper on decay \% of "Manfaluty" pomegranate fruits under cold storage during 2019 and 2020 seasons.

\begin{tabular}{|c|c|c|c|c|c|c|c|c|c|c|c|c|}
\hline \multirow{2}{*}{ Treatment } & \multicolumn{12}{|c|}{ Weeks of cold storage in Season 2019} \\
\hline & $\mathbf{0}$ & 2 & 4 & 6 & 8 & 10 & 12 & 14 & 16 & 18 & 20 & Mean \\
\hline Control & 0.00 & 0.00 & 0.00 & 0.00 & 0.00 & 0.00 & 6.66 & 13.33 & 20.00 & 26.66 & 33.33 & 9.09 \\
\hline Turmeric oil & 0.00 & 0.00 & 0.00 & 0.00 & 0.00 & 0.00 & 0.00 & 0.00 & 0.00 & 6.66 & 13.33 & 1.82 \\
\hline Ginger oil & 0.00 & 0.00 & 0.00 & 0.00 & 0.00 & 0.00 & 0.00 & 6.66 & 13.33 & 20.00 & 26.66 & 6.06 \\
\hline Waxed Paper & 0.00 & 0.00 & 0.00 & 0.00 & 0.00 & 0.00 & 0.00 & 0.00 & 6.66 & 13.33 & 20.00 & 3.64 \\
\hline Turmeric oil + waxed paper & 0.00 & 0.00 & 0.00 & 0.00 & 0.00 & 0.00 & 0.00 & 0.00 & 0.00 & 0.00 & 0.00 & 0.00 \\
\hline Ginger oil + waxed paper & 0.00 & 0.00 & 0.00 & 0.00 & 0.00 & 0.00 & 0.00 & 0.00 & 0.00 & 0.00 & 0.00 & 0.00 \\
\hline Mean & 0.00 & 0.00 & 0.00 & 0.00 & 0.00 & 0.00 & 1.11 & 3.33 & 6.67 & 11.11 & 15.55 & 3.43 \\
\hline \multirow{3}{*}{ LSD \% } & \multicolumn{2}{|c|}{ Period } & \multicolumn{2}{|c|}{7.74} & & & & & & & & \\
\hline & \multicolumn{2}{|c|}{ Treatment } & \multicolumn{2}{|c|}{3.43} & & & & & & & & \\
\hline & \multicolumn{2}{|c|}{ Period*Treatment } & \multicolumn{2}{|c|}{11.40} & & & & & & & & \\
\hline \multirow[b]{2}{*}{ Treatment } & \multicolumn{12}{|c|}{ Weeks of cold storage in Season 2020} \\
\hline & $\mathbf{0}$ & 2 & 4 & 6 & 8 & 10 & 12 & 14 & 16 & 18 & 20 & Mean \\
\hline Control & 0.00 & 0.00 & 0.00 & 0.00 & 0.00 & 0.00 & 13.33 & 20.00 & 26.67 & 33.33 & 40.00 & 12.12 \\
\hline Turmeric oil & 0.00 & 0.00 & 0.00 & 0.00 & 0.00 & 0.00 & 0.00 & 0.00 & 0.00 & 0.00 & 20.00 & 1.82 \\
\hline Ginger oil & 0.00 & 0.00 & 0.00 & 0.00 & 0.00 & 0.00 & 0.00 & 13.33 & 20.00 & 26.67 & 33.33 & 8.48 \\
\hline Waxed Paper & 0.00 & 0.00 & 0.00 & 0.00 & 0.00 & 0.00 & 0.00 & 6.67 & 13.33 & 13.33 & 26.67 & 5.45 \\
\hline Turmeric oil + waxed paper & 0.00 & 0.00 & 0.00 & 0.00 & 0.00 & 0.00 & 0.00 & 0.00 & 0.00 & 0.00 & 0.00 & 0.00 \\
\hline Ginger oil + waxed paper & 0.00 & 0.00 & 0.00 & 0.00 & 0.00 & 0.00 & 0.00 & 0.00 & 0.00 & 0.00 & 0.00 & 0.00 \\
\hline Mean & 0.00 & 0.00 & 0.00 & 0.00 & 0.00 & 0.00 & 2.22 & 6.67 & 10.00 & 12.22 & 20.00 & 4.65 \\
\hline \multirow{3}{*}{ LSD \% } & \multicolumn{2}{|c|}{ Period } & \multicolumn{2}{|c|}{7.07} & & & & & & & & \\
\hline & \multicolumn{2}{|c|}{ Treatment } & 4.5 & & & & & & & & & \\
\hline & \multicolumn{2}{|c|}{ Period*Treatment } & 15. & & & & & & & & & \\
\hline
\end{tabular}


Moreover, fruits treated with essential oils in combination with waxed paper did not show any decay from the beginning till the end of storage period in the contrastive studied seasons. On the other hand, at the end of storage period, untreated fruits scored the highest values of decay percentage which were $(33.33 \% \& 40.00 \%)$ during two studied seasons, respectively.

\subsection{Effect of some essential oils and waxed paper wrapping on chemical characteristics}

\section{Total Soluble Solids percentage (TSS \%)}

Data illustrated in Table 3 revealed that, there was a reliable increase of total soluble solids percentage in fruit juice with prolong the storage period. Looking to treatments means, it was observed that all treatments significantly decreased of total soluble solids percentage compared with control. On the other hand, in 2020 season, there was no significant difference between ginger oil treatment and control. the lowest values of total soluble solids percentage $(15.84 \% \& 15.90 \%)$ and $(16.26 \%$ \& 16.44 $\%)$ were recorded in fruits treated with turmeric oil or ginger oil in combination with waxed paper in both studied seasons, respectively compared to the control which gave the highest values $(16.53 \%$ \& $17.22 \%$ ) during 2019 and 2020 seasons, respectively.

According to obtained results at the end of storage period, it was noticed significant effect of interaction between tested treatments and storage periods. The lowest values of total soluble solids were $(16.73 \% \& 16.93 \%)$ and $(17.47 \% \& 17.47 \%)$ due to use turmeric oil or ginger oil plus waxed paper in both studied seasons, respectively. On the other hand, the corresponding values of total soluble solids percentage $(18.33 \% \& 18.47 \%)$ were due to control in both seasons, respectively.

\section{Total acidity percentage (TA \%)}

In general, the total acidity percentage in juice was gradually decreased by prolonging the storage duration. The obtained results in Table 4 apparent that all studied treatments caused significant increase in the total acidity percentage compared with untreated fruits. Comparison of treatments averages proved that combination between turmeric oil or ginger oil and waxed paper gave the highest total acidity percentage $(1.10 \% \& 1.08 \%)$ and $(1.09 \% \& 1.03 \%)$ in various studied seasons, respectively. Moreover, control gave the corresponding values of total acidity percentage $(0.93 \% \& 0.81 \%)$ in both seasons, respectively

Data revealed significant effect of interaction between storage treatments and storage periods. After 20 week of storage, in the first and second season, fruits treated with turmeric oil plus waxed paper and ginger oil plus waxed paper scored the highest values of total acidity percentage $(0.82 \%$ \& $0.81 \%)$ and $(0.88 \% \& 0.83 \%)$ in the two studied seasons, respectively compared to the lowest values $(0.58 \% \& 0.53 \%)$ that due to control in 2019 and 2020 seasons, respectively.

\section{Reducing sugars percentage}

Data related to weekly period's means revealed a significant increase of reducing sugar content in fruit juice by extending the storage period. Data illustrated in Table 6 regarding to treatments average that, all tested treatments led to significant effects on decreasing changes in reducing sugar content in stored fruits compared to control. Moreover, the combination of turmeric oil or ginger oil and waxed paper led to significant decrease of reducing sugar content $(10.08 \% \& 10.30 \%)$ and $(10.05 \% \& 10.43$ $\%$ ) during 2019 and 2020 seasons, respectively. On the other hand, untreated fruits gave significantly the highest values of reducing sugar $(11.63 \%$ \& 11.30) during the two studied seasons, respectively.

Obtained data revealed a significant effect of interaction between storage periods and the studied treatments at the end of storage period. Moreover, all treatments significantly decreased changes in reducing sugar. In the first and second seasons, turmeric oil plus waxed paper and ginger oil plus waxed paper scored the lowest values of reducing sugar $(12.36 \% \& 12.56 \%)$ and $(12.85 \% \& 13.16 \%)$ compared to control values $(15.25 \% \& 13.72 \%)$, respectively. 
Table 3: Effect of coating with some essential oils and wrapping with waxed paper on TSS \% of "Manfalouty" pomegranate fruits under cold storage during 2019 and 2020 seasons.

\begin{tabular}{|c|c|c|c|c|c|c|c|c|c|c|c|c|}
\hline \multirow{2}{*}{ Treatment } & \multicolumn{12}{|c|}{ Weeks of cold storage in Season 2019} \\
\hline & $\mathbf{0}$ & 2 & 4 & 6 & 8 & 10 & 12 & 14 & 16 & 18 & 20 & Mean \\
\hline Control & 15.00 & 15.47 & 15.47 & 16.00 & 16.33 & 16.60 & 16.67 & 16.73 & 17.27 & 17.93 & 18.33 & 16.53 \\
\hline Turmeric oil & 15.00 & 15.33 & 15.40 & 15.80 & 15.87 & 16.27 & 16.27 & 16.73 & 16.80 & 17.13 & 17.60 & 16.20 \\
\hline Ginger oil & 15.00 & 15.27 & 15.47 & 15.93 & 16.00 & 16.40 & 16.47 & 16.53 & 16.73 & 17.27 & 17.33 & 16.22 \\
\hline Waxed Paper & 15.00 & 15.40 & 15.47 & 15.80 & 16.07 & 16.27 & 16.33 & 16.47 & 17.13 & 17.47 & 18.27 & 16.33 \\
\hline Turmeric oil +waxed paper & 15.00 & 15.27 & 15.33 & 15.47 & 15.47 & 15.67 & 15.73 & 16.27 & 16.53 & 16.73 & 16.73 & 15.84 \\
\hline Ginger oil +waxed paper & 15.00 & 15.27 & 15.40 & 15.67 & 15.73 & 15.80 & 16.13 & 16.20 & 16.27 & 16.47 & 16.93 & 15.90 \\
\hline Mean & 15.00 & 15.33 & 15.42 & 15.78 & 15.91 & 16.17 & 16.27 & 16.49 & 16.79 & 17.17 & 17.53 & 16.17 \\
\hline \multirow{3}{*}{ LSD \% } & Period & & 0.21 & & & & & & & & & \\
\hline & Treatm & & 0.14 & & & & & & & & & \\
\hline & Period" & eatment & 0.46 & & & & & & & & & \\
\hline Period & \multicolumn{12}{|c|}{ Weeks of cold storage in Season 2020} \\
\hline Treatment & $\mathbf{0}$ & 2 & 4 & 6 & 8 & 10 & 12 & 14 & 16 & 18 & 20 & Mean \\
\hline Control & 15.20 & 16.13 & 16.87 & 16.87 & 16.93 & 17.27 & 17.73 & 17.93 & 17.93 & 18.13 & 18.47 & 17.22 \\
\hline Turmeric oil & 15.20 & 16.00 & 16.27 & 16.47 & 16.67 & 16.87 & 16.87 & 16.87 & 16.87 & 17.00 & 17.53 & 16.60 \\
\hline Ginger oil & 15.20 & 15.93 & 16.53 & 16.67 & 16.87 & 17.07 & 17.67 & 17.80 & 18.00 & 18.13 & 18.33 & 17.11 \\
\hline Waxed Paper & 15.20 & 15.27 & 16.27 & 16.33 & 16.53 & 16.67 & 16.73 & 17.27 & 17.47 & 17.53 & 18.33 & 16.69 \\
\hline Turmeric oil +waxed paper & 15.20 & 15.53 & 15.53 & 15.93 & 16.13 & 16.33 & 16.53 & 16.53 & 16.67 & 17.00 & 17.47 & 16.26 \\
\hline Ginger oil +waxed paper & 15.20 & 15.53 & 15.53 & 16.27 & 16.40 & 16.47 & 16.73 & 16.80 & 17.13 & 17.33 & 17.47 & 16.44 \\
\hline Mean & 15.20 & 15.73 & 16.17 & 16.42 & 16.59 & 16.78 & 17.04 & 17.20 & 17.35 & 17.52 & 17.93 & 16.72 \\
\hline \multirow{3}{*}{ LSD \% } & \multirow{3}{*}{\multicolumn{2}{|c|}{$\begin{array}{l}\text { Treatment } \\
\text { Period*Treatment }\end{array}$}} & 0.22 & & & & & & & & & \\
\hline & & & 0.16 & & & & & & & & & \\
\hline & & & 0.53 & & & & & & & & & \\
\hline
\end{tabular}


Table 4: Effect of coating with some essential oils and wrapping with waxed paper on total acidity \% of "Manfalouty" pomegranate fruits under cold storage during 2019 and 2020 seasons.

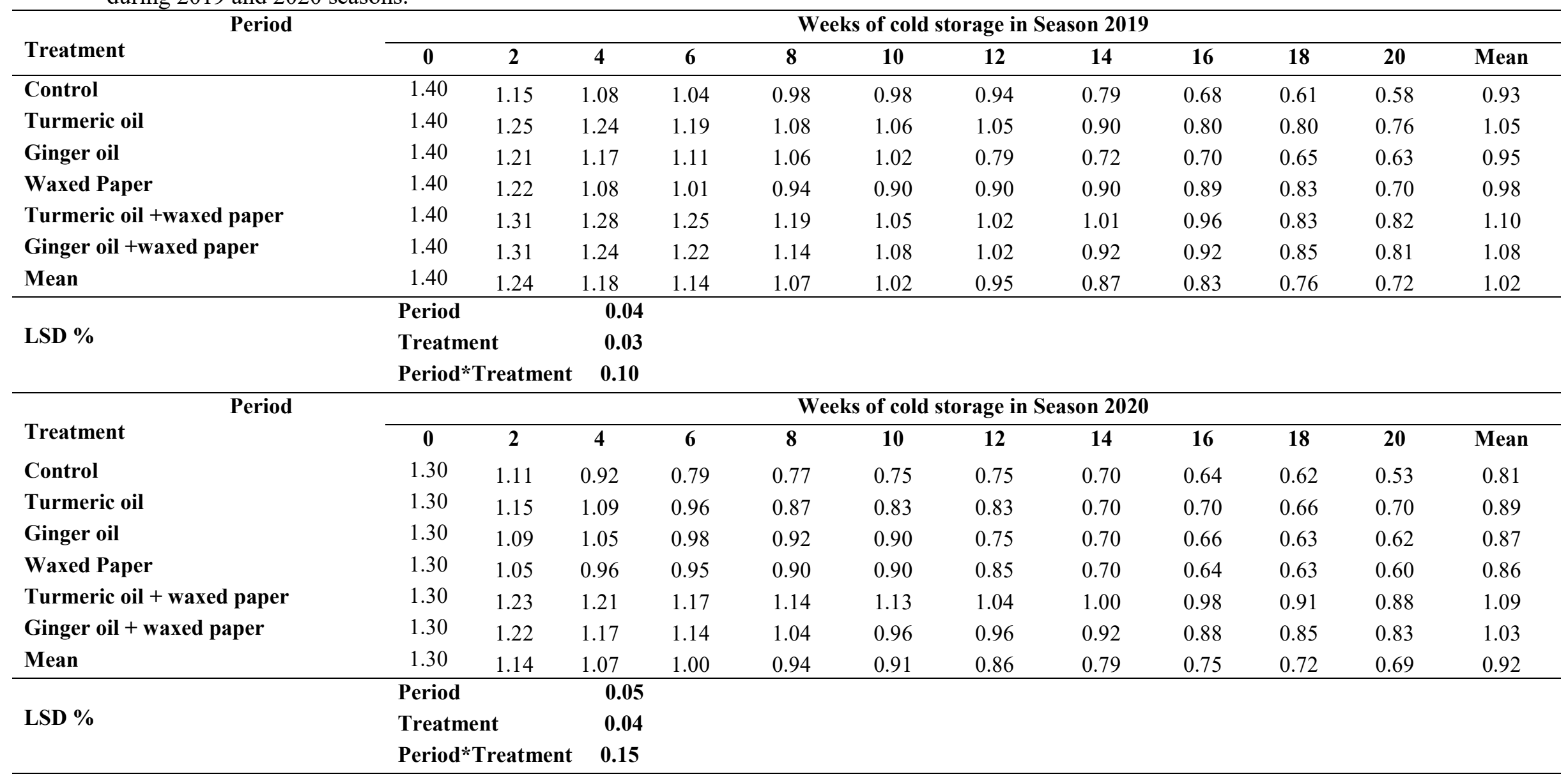


Table 5: Effect of coating with some essential oils and wrapping with waxed paper on reducing sugar \% of "Manfalouty" pomegranate fruits under cold storage during 2019 and 2020 seasons.

\begin{tabular}{|c|c|c|c|c|c|c|c|c|c|c|c|c|}
\hline \multirow[b]{2}{*}{ Treatment } & \multicolumn{12}{|c|}{ Weeks of cold storage in Season 2019} \\
\hline & $\mathbf{0}$ & 2 & 4 & 6 & 8 & 10 & 12 & 14 & 16 & 18 & 20 & Mean \\
\hline Control & 8.42 & 9.16 & 9.88 & 10.70 & 10.86 & 11.07 & 11.37 & 11.47 & 14.45 & 15.33 & 15.25 & 11.63 \\
\hline Turmeric oil & 8.42 & 8.99 & 9.48 & 9.60 & 10.06 & 10.40 & 11.20 & 12.40 & 12.47 & 12.58 & 13.35 & 10.81 \\
\hline Ginger oil & 8.42 & 9.11 & 9.52 & 9.52 & 10.23 & 10.77 & 10.83 & 11.27 & 12.30 & 13.71 & 13.73 & 10.86 \\
\hline Waxed Paper & 8.42 & 9.11 & 9.16 & 9.88 & 10.27 & 11.01 & 11.30 & 11.33 & 11.37 & 12.49 & 12.65 & 10.64 \\
\hline Turmeric oil + waxed paper & 8.42 & 8.94 & 8.90 & 9.21 & 9.70 & 9.80 & 10.04 & 10.55 & 11.30 & 11.71 & 12.36 & 10.08 \\
\hline Ginger oil + waxed paper & 8.42 & 8.97 & 9.29 & 9.34 & 10.03 & 10.40 & 10.79 & 10.80 & 10.80 & 11.86 & 12.56 & 10.30 \\
\hline Mean & 8.42 & 9.05 & 9.37 & 9.71 & 10.19 & 10.58 & 10.93 & 11.30 & 12.10 & 12.95 & 13.32 & 10.72 \\
\hline \multirow{3}{*}{ LSD \% } & Period & & 0.09 & & & & & & & & & \\
\hline & Treatn & & 0.08 & & & & & & & & & \\
\hline & Period & reatment & 0.27 & & & & & & & & & \\
\hline Period & \multicolumn{12}{|c|}{ Weeks of cold storage in Season 2020} \\
\hline Treatment & $\mathbf{0}$ & 2 & 4 & 6 & 8 & 10 & 12 & 14 & 16 & 18 & 20 & Mean \\
\hline Control & 8.21 & 10.16 & 10.54 & 10.57 & 10.95 & 11.05 & 11.27 & 11.43 & 12.87 & 13.51 & 13.72 & 11.30 \\
\hline Turmeric oil & 8.21 & 8.30 & 9.77 & 9.79 & 10.21 & 10.24 & 10.37 & 10.95 & 12.21 & 12.25 & 13.44 & 10.52 \\
\hline Ginger oil & 8.21 & 9.28 & 10.19 & 10.48 & 10.77 & 10.89 & 10.99 & 11.33 & 12.71 & 13.16 & 13.62 & 11.06 \\
\hline Waxed Paper & 8.21 & 9.45 & 9.63 & 10.08 & 10.21 & 10.42 & 11.04 & 11.40 & 11.43 & 12.51 & 13.38 & 10.71 \\
\hline Turmeric oil + waxed paper & 8.21 & 8.52 & 9.00 & 9.14 & 9.44 & 9.53 & 9.77 & 10.57 & 11.33 & 12.14 & 12.85 & 10.05 \\
\hline Ginger oil + waxed paper & 8.21 & 8.87 & 9.57 & 9.93 & 10.17 & 10.27 & 10.28 & 10.59 & 11.47 & 12.18 & 13.16 & 10.43 \\
\hline Mean & 8.21 & 9.10 & 9.78 & 10.00 & 10.29 & 10.40 & 10.62 & 11.05 & 12.00 & 12.63 & 13.36 & 10.68 \\
\hline \multirow{3}{*}{ LSD \% } & Period & & 0.19 & & & & & & & & & \\
\hline & \multicolumn{2}{|c|}{ Treatment } & 0.16 & & & & & & & & & \\
\hline & \multicolumn{2}{|c|}{ Period*Treatment } & 0.54 & & & & & & & & & \\
\hline
\end{tabular}




\section{Discussion}

Recently, many studies have focused on applying post-harvest treatments for maintain fruits quality that includes color, taste, flavor and shape for the longest possible period, also with increasing consumer demand for natural products without use of any preservatives or chemicals that affect human health. The main problems affecting of postharvest quality of pomegranate fruits are physiological weight loss and decay development (Elyatem \& Kader, 1984).

Weight loss percentage of fruits was increasing with prolonging storage period. Fruit weight loss was probably attributed to high porosity of the pomegranate peel that led to increasing in respiration and transpiration ratio. In addition to, difference in water vapor pressure between the fruit tissue and the outside atmosphere (Kader, 2006 and Nasrin et al., 2018). coating with oils and wrapping treatments act as a semi-permeable barrier between fruit peel and outside atmosphere against O2, CO2 and moisture, so they have ability to decreasing respiration and water loss (Zagory \& Kader, 1988 and Nasrin et al., 2020).

Previous results about positive effect of the combination between essential oils coating and wrapping on the decreasing of weight loss during storage are in accordance with the obtained of Wijewardane \& Guleria (2013) on apple fruits and Kahramanoğlu et al., (2018) on pomegranate fruits In addition to Sebastian \& Kumar (2018) on Guava fruits.

It was noticed that Penicillium sp is mostly the main cause of pomegranate fruit decay during storage period. Essential oils rich phenolic compounds that cause changes of microbial cell permeability through interaction with membrane proteins. This would cause a deformation in structure and functional of fungal cell (Rattanapitigorn et al., 2006). Moreover, the turmeric oil and ginger oil is used as food coating because of its antioxidant, antifungal and antiviral properties (Roth et al., 1998 and Riaz et al., 2015).

Concerning the effect of coating with essential oils and wrapping on fruit decay percentage, our previous results were in agreement with Badawy et al., (2016) and Kahramanoğlu et al., (2018). On the other hand, these results were disagreement with D'Aquino et al., (2010).

The raise in total soluble solids and sugar content during storage period can be due to the degradation of insoluble polysaccharides to simple soluble sugars. On the other hand, another reason may be due to fruit moisture loss through evaporation or transpiration processes in fruits during storage duration, which led to increasing in juice concentration (Singh \& Mohammed, 1997 and Hussein et al., 2003). Also, Increasing in reducing sugar concentration during storage may be attributed to Inversion of non-reducing sugars into reducing sugars, increasing in physiological weight loss and reducing in acidity of stored fruits (Srivastava \& Said, 2019). Such changes are slower through applications of coating or wrapping on stored fruits (Hayat \& Rathore, 2005, Wijewardane \& Guleria, 2009 and De Paula et al., 2018)

Obtained results was in agreement with Shaarawi \& Nagy (2017), Kahramanoğlu et al., (2018) and Safizadeh (2019) who showed that using essential oil coating and wrapping delayed the reduce in percentage of total acidity during storage period for pomegranate fruits. On the other hand, Artés et al., (2000) and Fatma et al., (2017) observed that wrapped pomegranate fruits with polypropylene or polyethylene film scored the lowest acidity percentage compared to control stored fruits.

Pomegranate juice is rich in organic acids such as citric, malic, fumaric, tartaric, lactic and acetic acids; however citric acid is the main contributor to the acidity of pomegranate juice. The decrease in acidity percentage during storage period may be due to consumption of main acid through fruit respiration process (Melgarejo et al., 2000). Coating with essential oils and wrapping slow fruits respiration rate, therefore the utilization of organic acid in respiration enzymatic reactions delayed (Cong et al., 2007).

\section{Conclusion}

On the light of obtained results of this study, it could be concluded that coating with essential oils (turmeric oil and ginger oil) and wrapping with waxed paper maintained the quality of Manfalouty pomegranate fruits for 20 week under cold storage. Moreover, the combination between turmeric oil or ginger oil and waxed paper was more effective and gave the best results on keeping fruits quality for the longest possible storage period. 


\section{References}

Analytical Software, 2005. Statistix 8.1 for Windows analytical software. Tallahassee, Florida.

A.O.A.C., 2005. Official method of analysis of AOAC International. 18th Ed. Suite 500 481, North Frederick Avenue, Gaithersburg, Maryland, 20877-2417. U.S.A.

Artés, F., R. Villaescusa, and J.A. Tudela, 2000. Modified atmosphere packaging of pomegranate. Journal of Food Science, 65(7): 1112-1116.

A.O.A.C., 1985. Official methods of analysis. 14th Ed. Washington, D.C., U.S.A.

Badawy, I.F., R.A. Ibrahim, and F.M. Gouda, 2016. Effect of some post-harvest treatments on storability and quality of Manfalouty pomegranate fruits at ambient temperature. Assiut Journal Agriculture Science, 47(3): 78-91.

Chen, P.M., and W.M. Mellenthin, 1981. Effects of harvest date on ripening capacity and post-harvest life of d'Anjou pear. Journal American Society Horticulture Science, 106(1): 38-42.

Cong, F., Y. Zhang, and W. Dong, 2007. Use of surface coatings with natamycin to improve the storability of Hami melon at ambient temperature. Postharvest Biology and Technology, 46(1): 71-75.

D’Aquino, S., A. Palma, M. Schirra, A. Continella, E. Tribulato, and S. La Malfa, 2010. Influence of film wrapping and fludioxonil application on quality of pomegranate fruit. Postharvest Biology and Technology, 55(2): 121-128.

De Paula, R.L., B.C. Maniglia, O.B.G. Assis, and D.R. Tapia-Blácido, 2018. Evaluation of the turmeric dye extraction residue in the formation of protective coating on fresh bananas (Musa acuminata cv.'Maçã'). Journal of food science and technology, 55(8): 3212-3220.

Elyatem, S.M., and A.A. Kader, 1984. Post-harvest physiology and storage behavior of pomegranate fruits. Science Horticulture, (24): 287-298.

Fatma K.M. Shaaban, Naglaa M.A., Yassin and Thanaa S.M. Mahmoud, 2017. Impact of Potassium Sorbate and Polyethylene Film Wrapping Treatments on Storability of Wonderful Pomegranates. Middle East Journal of Applied Sciences, 7(2): 289-298.

Hayat, I., T. Masud, and H.A. Rathore, 2005. Effect of coating and wrapping materials on the shelf life of apple (Malus domestica cv. Borkh). International Journal food safety, 5: 24-34.

Holland, D., K. Hatib, and I. Bar-Ya'akov, 2009. Pomegranate: botany, horticulture, breeding. Horticultural reviews, 35(2): 127-191.

Hussein, M.A., T.K. El-Mahdy, and A.A. Ibrahim, 2003. Effect of calcium chloride and gibberellic acid treatments on anna and dorsett golden apples during storage. Assiut Journal Agriculture Science, 32(2): 185-200.

Jemilakshmi, T.V., L. Rakshana, S.K. Priya, B. Aishwarya, and C. Anithaee, 2020. Postharvest Quality Enhancement of Fruits and Vegetables Using Edible Coatings: A Review. Journal of Critical Reviews, 7(7): 786-790.

Kader, A.A., and M.L. Arpaia, 2002. Postharvest handling systems: Subtropical fruits. In: Kader A.A. (E.d.): Postharvest Technology of Horticultural Crops. University of California, U.S.A., 375384.

Kader, A., A. Chordas, and S. Elyatem, 1984. Responses of pomegranates to ethylene treatment and storage temperature. California Agriculture, 38(7): 14-15.

Kader, A.A., 2006. Postharvest biology and technology of pomegranates. In Pomegranates, 229-238. CRC Press.

Kahramanoğlu, İ., M. Aktaş, and Ş. Gündüz, 2018. Effects of fludioxonil, propolis and black seed oil application on the postharvest quality of "Wonderful" pomegranate. PLoS One, 13(5): 0198411.

Melgarejo, P., D.M. Salazar, and F. Artés, 2000. Organic acids and sugars composition of harvested pomegranate fruits. European Food Research and Technology, 211(3): 185-190.

Nasrin, T.A.A., M.N. Islam, M.A. Rahman, M.S. Arfin, and M.A. Ullah, 2018. Evaluation of postharvest quality of edible coated mandarin at ambient storage. International Journal of Agricultural Research, Innovation and Technology, 8(1): 18-25.

Nasrin, T.A.A., M.A. Rahman, M.S. Arfin, M.N. Islam, and M.A. Ullah, 2020. Effect of novel coconut oil and beeswax edible coating on postharvest quality of lemon at ambient storage. Journal of Agriculture and Food Research, 2, 100019. 
Rattanapitigorn, P., M. Arakawa, and M. Tsuro, 2006. Vanillin enhances the antifungal effect of plant essential oils against Botrytis cinerea. The International Journal of Aromatherapy, 16(3): 193198.

Riaz, H., A. Begum, S.A. Raza, Z.M. Khan, H. Yousaf, and A. Tariq, 2015. Antimicrobial property and phytochemical study of ginger found in local area of Punjab, Pakistan. International Current Pharmaceutical Journal, 4(7): 405-409.

Roth, G.N., A. Chandra, and M.G. Nair, 1998. Novel bioactivities of Curcuma longa constituents. Journal of Natural Products, 61(4): 542-545.

Safizadeh, M.R., 2019. The effect of various film packaging, wax coating and storage conditions on the shelf life and quality of pomegranate fruits. Journal of Horticultural Research, 27(2): 47-54.

Sebastian, S., K.L. Bala, and A. Kumar, 2018. Effect of essential oil coatings and storage conditions on shelf-life of guava (psidiumguajava) and amla (emblica officinalis). The Allahabad Farmer, 74(3).

Shaarawi, S.A., and K.S. Nagy, 2017. Effect of modified atmosphere packaging on fruit quality of "Wonderful" pomegranate under cold storage conditions. Middle East Journal of Agriculture Research, 6(2): 495-505.

Singh U.B., and S. Mohammed, 1997. Comparative efficiency of wax emulsion and rice starch on postharvest shelf life of fully ripe guava fruits. Journal Food Science Technology, 34: 519-522.

Snedecor, G.W., and W.G. Cochran, 1990. Statistical Methods. 6th EdIowa State University Press. Ames, Iowa, 507.

Srivastava, S., and P. Said, 2019. Application of modified atmosphere packaging using silicone membrane system for shelf life extension of pomegranate (Punica granatum L.) and its effect on physico-chemical properties. Food Quality and Safety, 3(3): 145-155.

Tripathi, P., N.K. Dubey, and A.K. Shukla, 2008. Use of some essential oils as post-harvest botanical fungicides in the management of grey mould of grapes caused by Botrytis cinerea. World Journal Microbiol Biotechnol, 24(1): 39-46.

Wijewardane, R.M.N.A., and S.P.S. Guleria, 2009. Combined effects of pre-cooling, application of natural extracts and packaging on the storage quality of apple (Malus domestica) cv. royal delicious. Tropical Agricultural Research, 21(1): $10-20$.

Wijewardane, R.N.A., and S.P.S. Guleria, 2013. Effect of pre-cooling, fruit coating and packaging on postharvest quality of apple. Journal of food science and technology, 50(2): 325-331.

Yamashita, F., L.H.D.S. Miglioranza, and L.D.A. Miranda, 2002. Effects of packaging and temperature on postharvest of atemoya. Revista Brasileira de Fruticultura, 24(3): 658-660.

Zagory, D., and A.A. Kader, 1988. Modified atmosphere packaging of fresh produce. Food Technology, 42(9): 70-77. 